See discussions, stats, and author profiles for this publication at: https://www.researchgate.net/publication/268506045

New species of Potamocoris Hungerford (Heteroptera, Potamocoridae) from Costa Rica and a key to the species

Article in Zootaxa $\cdot$ November 2014

Dol: 10.11646/zootaxa.3884.5.6

\section{CITATIONS}

4

2 authors:

Federico Herrera

National University of Costa Rica

23 PUBLICATIONS 34 CITATIONS

SEE PROFILE
READS

107

Monika Springer

University of Costa Rica

67 PUBLICATIONS 533 CITATIONS

SEE PROFILE

Some of the authors of this publication are also working on these related projects:

Project Diversidad y distribución de libélulas (Insecta: Odonata) en Costa Rica View project

Project Chironomidae (Diptera) of Costa Rica View project 
http://dx.doi.org/10.11646/zootaxa.3884.5.6

http://zoobank.org/urn:lsid:zoobank.org:pub:D213951B-E005-4F16-B8A8-4D713CBE0B24

\title{
New species of Potamocoris Hungerford (Heteroptera, Potamocoridae) from Costa Rica and a key to the species
}

\author{
FEDERICO HERRERA ${ }^{1} \&$ MONIKA SPRINGER ${ }^{2,3}$ \\ ${ }^{1}$ Escuela de Biología, Universidad Nacional (UNA), Heredia, Costa Rica. E-mail: fede.herrera.madrigal@gmail.com \\ ${ }^{2}$ Escuela de Biología, Universidad de Costa Rica (UCR), San Pedro Montes de Oca, San José Costa Rica \\ ${ }^{3}$ Centro de Investigación en Ciencias del Mar y Limnología (CIMAR),Universidad de Costa Rica
}

\begin{abstract}
A new potamocorid species, Potamocoris sitesi NEW SPECIES, with its two wing morphs (coleopteroid and macropterous) are described from Costa Rica. Descriptions are supported with photographs and illustrations. Parameres become progressively narrower, ending in a sharp needle-like point. This is the third species of Potamocoris known from Central America. A key to the species of the genus is provided.
\end{abstract}

Key words: Hemiptera, Naucoroidea, Central America, water bugs, diversity

\section{Resumen}

Se describe una nueva especie de potamocórido para Costa Rica, Potamocoris sitesi NUEVA ESPECIE, con sus dos morfos de alas (coleopteroide y macróptero). Las descripciones morfológicas están apoyadas con fotografías e ilustraciones. Los harpagones son progresivamente más estrechos, terminando en punta aguda. Hasta el momento, es la tercera especie de Potamocoris conocida para Centroamérica. Se provee una clave para las especies del género.

Palabras clave: Hemiptera, Naucoroidea, Centroamérica, chinche acuático, diversidad

\section{Introduction}

The family Potamocoridae has 10 described species, only two of which are present in Central America; the rest are confined to the South American continent. Potamocoris beckeri La Rivers, 1950 has been reported from Honduras, Guatemala and Mexico (Herrera \& Springer 2012). Polhemus \& Carrie (2013) described the second species present in Mesoamerica, Potamocoris isbiru from Belize, and synonymized the genus Coleopterocoris Hungerford, 1942 under the genus Potamocoris Hungerford, 1941. Herrera \& Springer (2012) reported the family for the first time in Costa Rica including both genera known at that time. This new species from Costa Rica represents the third Central American species of Potamocoridae.

\section{Material and methods}

Measurements in this paper are the same as those used by Longo et al. (2005), and were taken using the computer software Motic Image Plus 2.0. All measurements are given in millimeters. Specimens measured were preserved in ethanol $70 \%$. It was not necessary to conduct any type of dissection since male parameres were visible. The genital capsule and subgenital plate were drawn using the computer software Macromedia Flash Professional 8.0. 